\title{
Hepatit C İnfeksiyonlarının Laboratuvar Tanısı, Karșılașılan Güçlükler ve Güncel Tanı Algoritması
}

\section{Laboratory Diagnosis of Hepatitis C Infections, Difficulties and Current Diagnostic Algorithm}

\author{
Fatih ȘAHINER'(ID), Ramazan GÜMRAL'(ID)
}

${ }^{1}$ Sag̃lık Bilimleri Üniversitesi Gülhane Tıp Fakültesi, Tıbbi Mikrobiyoloji Anabilim Dalı, Ankara, Türkiye 2020;25(2):139-53.

\section{ÖZ}

Hepatit C virüsü (HCV) başlıca infekte kişilerin kan ve vücut sıvılarılla temas sonucu bulaşan, insanlarda akut ve kronik hepatite neden olan ve diğer hepatit virüslerinden farklı olarak yüksek oranda kronikleşme potansiyeli taşıyan bir infeksiyon etkenidir. Antijenik yapılarının yüksek oranda değişkenlik göstermesi nedeniyle henüz bir koruyucu aşı geliştirilememiş olsa da, yakın zamanda kullanıma giren direkt etkili antiviral ilaçlar ile HCV infeksiyonlarının kalıcı tedavisi mümkün hale gelmiştir. Tedavi başarısında tedavi öncesi genotip-subtip belirlenmesi ve tedavi süresince kantitatif moleküler analizlerle viral yük takibi gibi laboratuvar testleri kritik öneme sahiptir. $\mathrm{HCV}$ infeksiyonlarının laboratuvar tanısı ayrıca kan ve kan ürünlerinin taranması ve epidemiyolojik sürveyans gibi infeksiyon kontrol önlemleri için de önemlidir. HCV tanısında karşılaşılan en önemli güçlükler düşük pozitif serolojik test sonuçları, serolojik pencere dönemi, immünsüpresif hastalarda antikor üretiminin olmayışı, çok sayıda genotip-subtip varlığının ve genomik varyasyonların primer-prob tasarımını güçleştirmesi gibi kısıtıııklardır. Geçmişte düşǚk titreli serolojik test sonuçlarını doğrulamak için rekombinant proteinlerin kullanıldığı immünblotlama testlerine başvurulmuştur. Günümüzde ise bu testlerin yerini yüksek duyarlıık ve özgüllüğe sahip olmaları yanında, akut infeksiyonlarda erken tanı imkanı sunan moleküler testler almıştır. Bu makalede HCV infeksiyonlarının tanı ve takibinde kullanılan yöntemlerin avantajları ve kısıtııkları ele alınmış ve HCV infeksiyonlarının yönetiminde mevcut testlerin kullanımına dayalı güncel tanı algoritması gözden geçirilmiştir.

Anahtar Kelimeler: Anti-HCV; HCV-RNA; Akut infeksiyon; Kantitasyon

\section{ABSTRACT}

Laboratory Diagnosis of Hepatitis C Infections, Difficulties and Current Diagnostic Algorithm

Fatih ȘAHINER', Ramazan GÜMRAL ${ }^{1}$

${ }^{1}$ Department of Medical Microbiology, Faculty of Gulhane Medicine, University of Health Sciences, Anakara, Turkey

Hepatitis $\mathrm{C}$ virus (HCV) is an infectious agent transmitted mainly by the contact of blood and body fluids of infected people, causing acute and chronic hepatitis in humans with a high potential for chronicity, unlike other hepatitis viruses. Although a protective vaccine has not yet been developed due to the extreme variability of its antigenic structures, it has become possible to permanently treat HCV infections with direct-acting antiviral drugs recently introduced. Laboratory tests such as determination of genotype-subtype before

Geliș Tarihi/Received: 26/07/2019 - Kabul Ediliș Tarihi/Accepted: 02/12/2019

${ }^{\odot}$ Telif Haklı 2020 Flora. Makale metnine www.floradergisi.org web adresinden ulașılabilir 
the start of treatment and viral load monitoring by using quantitative molecular analyzes during treatment are critical for the success of treatment. Laboratory diagnosis of HCV infections is also important for infection control measures such as screening of blood and blood products and epidemiological surveillance. The most important difficulties encountered in the diagnosis of HCV are low positive serological test results, serological window period, lack of antibody production in immunosuppressive patients, the presence of multiple genotype-subtypes and genomic variations that complicate primary-probe design. In the past, immunoblotting tests using recombinant proteins had been used to confirm low titer serological test results. Nowadays, these tests have been replaced by molecular tests that provide early detection of acute infections as well as having high sensitivity and specificity. In this article, advantages and limitations of the methods used in the diagnosis and follow-up of HCV infections are discussed, and the current diagnostic algorithm based on the use of available tests in the management of HCV infections is reviewed.

Key Words: Anti-HCV; HCV-RNA; Acute infection; Quantitation

\section{GíRiș}

Hepatit C virüsü (HCV), 1989 yilında non-A non-B kronik hepatitin ana nedeni olarak tanımlanmıs olan, tek iplikli pozitif polariteli RNA genomu tassıan bir flavivirüstür ${ }^{[1,2]}$. Kronik $\mathrm{HCV}$ infeksiyonunun gerçek prevalansı hakkında kesin bir kanit yoktur, ancak 185 milyondan fazla kișinin kronik hepatit $\mathrm{C}$ ile yașadığı ve infeksiyonun her yil yaklașik 500 bin ölüme neden olduğu tahmin edilmektedir ${ }^{[3,4]}$. Dünya nüfusunun yaklașık \%3'ü HCV ile infekte iken, ülkemizde bu oran yaklașık olarak \%1'dir ${ }^{[4,5]}$. HCV infeksiyonlarının tanısında klinik belirti ve bulguların değerlendirilmesi, karaciğer enzimleri bașta olmak üzere biyokimyasal analizler, karaciğer dokusunun fibrozis derecesi (ISHAK ve Knodell skorlamaları) ve siroz varlığı gibi patolojik değișiklikler yönünden incelenmesi tedavi planlaması ve hasta yönetiminde klinik öneme sahiptir ${ }^{[6,7]}$. Benzer klinik belirtiler ve nonspesifik laboratuvar bulguları $\mathrm{HCV}$ dıșında farklı hastalıklarda ve diğer viral infeksiyonlarda da görülebildiği için spesifik testler ile ayırıcı tanı yapilmasına gereksinim duyulur. HCV infeksiyonlarının spesifik tanısı bașlıca hasta serumunda virüse özgü antikorların gösterilmesi veya viral nükleik asit (HCV-RNA) varlığının saptanması gibi mikrobiyolojik testler temelinde yapilır. Son yıllarda HCV infeksiyonlarının tedavisinde önemli ilerlemeler kaydedilmiş ve değișen klinik ihtiyaçları karşılamak adına tanı paradigmasında bazı değișiklikler olmustur ${ }^{[8]}$. Günümüzde $\mathrm{HCV}$ infeksiyonlarının yönetiminde (antiviral tedavinin planlanması ve tedavi takibinde) genotip tayini yapabilen ve kantitatif sonuçlar sunan moleküler yöntemler kritik öneme sahip testler haline gelmiștir.

\section{NONSPESIFIK KLINIK ve LABORATUVAR BULGULARI}

HCV infeksiyonunun klinik tanısı basslica karaciğer tutulumu ve hasarı olmak üzere etkilenen organlardan kaynaklanan hastalık semptomlarının değerlendirilmesiyle yapilır. Bununla beraber, akut HCV infeksiyonlarının sadece \%15-30'u semptomatiktir ${ }^{[9]}$. Akut infeksiyonlar grip benzeri hafif belirtilerle gecirilebilir, ancak sarılık (olguların \%10-15'inde), idrar renginde koyulașma, anoreksi ve ceșitli abdominal rahatsızlıklar seklinde belirtiler de görülebilir ${ }^{[10,11]}$. Olguların \%70-85'inde infeksiyon kronikleșir ve 20-30 yil içinde hastaların \%17-55'inde siroza, \%1-23'ünde hepatoselüler kansere ilerleyebilir ${ }^{[10]}$. HCV infeksiyonlarında biyokimyasal, hematolojik ve histopatolojik parametrelerde cessitli değișiklikler gözlenir. Karaciğer hasarı ve hastanın genel durumunun nonspesifik göstergeleri arasında karaciğer enzimlerinde yükselme, albumin, globulin, bilirubin, üre ve kreatinin değerleri, protrombin zamanı ve "International Normalized Ratio (INR)" değerleri yer alır ${ }^{[12]}$. Histopatolojik değișikliklerden en önemlisi olan fibrozis derecesini değerlendirmek için sıklıkla karaciğer biyopsisi uygulanır. Bununla beraber karaciğerdeki hasarın durumunu değerlendirmek için ultrasonografi, transient karaciğer elastografisi, serum aspartat aminotransferaz/platelet oranı (APRI) indeksi, FibroTest ve FIB4 testleri gibi invaziv olmayan yöntemler de kullanılabilir $[6,13]$.

\section{HCV INFEKSIYONLARININ SPESIFIK TANISI}

HCV infeksiyonlarının mikrobiyolojik tanısı bașlica serum veya plazma örneklerinde viral antijenlere karșı oluşan antikorların gösterilmesi ve 
HCV-RNA saptanması esasına dayalıdır. Doğrudan viral antijen düzeylerini (kor antijeni gibi) ölçen testler de geliștirilmiștir ${ }^{[8]}$. Genotip-subtip tayini, viral yükü gösteren kantitatif testler ve antiviral direnc testleri de mikrobiyolojik analizler arasında yer alır. HCV rutin hücre kültürlerinde üretilememektedir, bu nedenle tanısal amaçlı kullanılan bir in vivo veya in vitro kültür sistemi bulunmamaktadır. Bununla beraber, antiviral ilac gelistirme çalıșmaları ve așı calıșmalarının yürütüldüğü araștırma laboratuvarlarında Huh7 hücrelerinde, șimerik farelerde (insan karaciğeri transplante edilmiș) ve sempanzelerde düsuik replikasyon düzeyli de olsa virüs üretilebilmektedir ${ }^{[1,14]}$.

\section{HCV INFEKSIYONLARINDA SEROLOJIK TANI}

HCV infeksiyonlarının serolojik tanısı "Enzyme Linked Immunosorbent Assay (ELISA)" ve "Chemiluminescence Immuno Assay (CLIA)" temelli yöntemlerle $\mathrm{HCV}$ spesifik antijen veya antikorların gösterilmesini kapsamaktadır. Serolojik testlerle $\operatorname{IgM}$ ve $\operatorname{IgG}$ antikorlarının varlığı ve titresi ile $\operatorname{IgG}$ antikorları için avidite indeksi araștırılabilmektedir ${ }^{[15]}$. Anti-HCV pozitifliği kișinin $\mathrm{HCV}$ ile karsılaștığını göstermekte, ancak infeksiyonun temizlenme durumu (clearance), akut veya kronik aktif infeksiyon ayrımı ve reinfeksiyon-reaktivasyon olasılıkları hakkında güçlü bir veri sağlamamaktadır. Ayrıca, bağıșıklığı baskılanmıs hastalar, insan immünyetmezlik virüsü (HIV) infeksiyonu olan kișiler ve hemodiyaliz hastalarında saptanabilir düzeyde HCV antikoru bulunmayabileceği için bu hastalar HCV infeksiyonları açısından değerlendirilirken serolojik testler yerine doğrudan HCV-RNA testleri tercih edilmelidir ${ }^{[16]}$.

\section{ELISA ve CLIA Temelli Testler}

Anti-HCV antikorlarını saptamaya yönelik testler HCV infeksiyonlarının tanı ve taramasında ilk bașurulan (birinci basamak) testlerdir. Farkl duyarlılık oranlarına sahip olan bu testlerin cok sayıda ticari formu geliștirilmiș ve kullanıma sunulmustur $^{[17]}$. HCV-ELISA-CLIA testlerinin tasarımlarında antijen olarak kor, NS3 ve NS4 gibi korunmus gen bölgeleri tarafından eksprese edilen proteinlerin yanında, E2-HVR bölgeleri, NS4 ve NS5 bölgesince kodlanan rekombinant proteinler de kullanılmaktadır ${ }^{[7,11,17,18]}$. Rekombinant prote- inler ile spesifik olmayan reaksiyonların önlenmesi için serolojik testlerde maya ve Escherichia coli proteinlerini içeren bir seyreltme tamponu kullanılır $^{[7]}$. HCV replikasyon basamakları ve $\mathrm{HCV}$ proteinlerine dair bilgilerin açıklığa kavușturulmasına paralel olarak serolojik tanı testlerinin içerdiği antijenlerin kompozisyonunda yıllar içerisinde değisiklikler olmus ve testlerin duyarlılıklarında önemli ilerlemeler sağlanmıștır.

Birinci nesil testler 1992 yılından itibaren kullanıma sunulmus olup, HCV genomunun NS4 bölgesinde kodlanan yapisal olmayan rekombinant bir protein olan c100-3'e karș gelisen antikorlar1 saptayacak sekilde tasarlanmıstır ${ }^{[11]}$. Kullanılan antijenin yapisal bir protein olmaması nedeniyle test tüm HCV olgularını saptayamıyordu. Bu ilk testlerin duyarlılığı \%70-80 olup, birçok hastada yanlıș-pozitif sonuc vermiștir ${ }^{[19]}$. Ayrıca, antikor varlığını saptama süresi infeksiyon bașlangıcından 15-16 hafta sonrasina kadar uzundu ${ }^{[11]}$.

İkinci nesil testler, NS4 rekombinant proteinlere (5-1-1 ve c100) ilave olarak kor bölgesinden (c22-3) ve NS3 bölgesinden (c33c veya c200) türetilmiş iki rekombinant protein daha içerir ${ }^{[11,17,19]}$. İkinci nesil testlerle akut infeksiyonlarda infekte bireylerin \%92-95'i tespit edilebilir olmus, pencere dönemi de 10 haftaya kadar kısalmıstır ${ }^{[7,11]}$.

Üçüncü nesil testler 1996 yılında lisans alarak kullanıma sunulmuștur. E2 proteininin HVR bölgesi, NS4A, NS4B ve NS5A bölgelerine ait antijenlerin eklendiği üçüncü nesil testlerde kor ve NS3 proteinleri de yeniden yapilandırılmıstır ${ }^{[11,17]}$. c100 ve 5-1-1 antijenlerinin yerine c100 peptidi, c22'nin yerine c22p peptidi eklenmis, c33c'nin ise yoğunluğu artırılmıștır ${ }^{[17]}$. U̇çüncü nesil testlerin geliștirilmiș duyarlılığı (\%97) NS3 antijeninin artan reaktivitesine atfedilirken, NS5 antijeninin ilave yanlıș-pozitif sonuçar üretebileceği öne sürülmüștür ${ }^{[7]}$. Yalancı pozitiflik oranlarının yükselmesi nedeniyle bazı firmalar test içeriğinden NS5 antijenini cıkarıp, antijen kompozisyonunda küçük değișiklikler yaparak duyarlılık ve özgüllüğü arttırmișlardır ${ }^{[20]}$. Üçüncü nesil testler pencere dönemini 4-8 haftaya kısaltmıștır ${ }^{[11]}$.

Kor bölgesinden iki epitop kullanılan ve NS3, NS4A, NS4B, NS5A gibi proteinlerin ceșitlendiril- 
diği dördüncü nesil testlere genotip $1 \mathrm{a}, 1 \mathrm{~b}, 2$ ve 3'e ait genotip spesifik NS3 ve NS4 proteinleri eklenmiștir. Böylece testlerin duyarlılıkları üçüncü kușak testlere göre daha yüksek (\%99-100) hale gelmiștir $^{[21]}$. Bu testler pencere dönemini 17 güne kadar (ortalama 26.8 gün) kısaltmıstır ${ }^{[11,19] . ~}$

Hasta serumunda, ilk tespit edilebilen $\mathrm{HCV}$ spesifik antikorlar, NS3 bölgesini (anti-c33) ve kor (anti-c22 veya anti-kapsit) antijenlerini hedefleyen antikorlardır. Daha sonraki dönemde ise NS4 bölgesine ve zarf proteinlerine (E1 ve E2) karș1 olușan antikorlar saptanabilir düzeylere ulașır ${ }^{[18]}$. Çoğu hastada viral klerens ve iyileșme sonrası anti-HCV antikorları 10-20 y1 gibi uzun bir süre daha pozitif olarak saptanabilmektedir ${ }^{[18]}$.

Advia Centaur XP (Bayer-Siemens, Almanya), Architect i2000SR (Abbott, ABD) ve LiaisonXL Murex (DiaSorin, İtalya) kemilüminesans temelli yeni nesil testlere örnek olarak verilebilir ${ }^{[4,17]}$. Anti-HCV testlerinde reaktivite eșiği olarak, test örneği (sample) optik dansitesinin eșik değere (cut-off) oraniyla elde edilen S/Co (sinyal-cut off) değeri kullanılmakta ve S/Co değerinin $\geq 1$ olması üretici firmaların önerisiyle pozitif olarak kabul edilmektedir ${ }^{[4]}$. Test sonucunun $\% 95$ olasılikla gerçek pozitif olarak kabul edildiği S/Co değeri yaygın kullanilan "Food and Drug Administration (FDA)" onaylı ELISA ve CLIA temelli ticari testlerde $\geq 3.8$ ila $\geq 11$ aralı̆̆ında değișmektedir ${ }^{[22]}$.

"Recombinant Immunoblot Assay (RIBA)" ve "Line Immuno Assay (LIA)" Testleri

Düșük pozitif anti-HCV değerlerinin yalancı pozitif olma olasılığına karșı bu sonuçarın RIBA veya LIA gibi özgüllüğü daha yüksek testlerle doğrulanmasına gereksinim duyulmustur ${ }^{[17]}$. RIBA-II (Ortho Diagnostic Systems, ABD) ve Matrix HCV (Abbott, ABD) testleri bu amaçla kullanılan ticari immünoblot testleri iken, Inno-LIA HCV Score (Innogenetics, Belçika) ise ticari üçüncü nesil LIA testidir ${ }^{[17,23]}$.

RIBA testleri ELISA yönteminin modifikasyonuna dayalı bir sistemdir ${ }^{[7]}$. RIBA testleri de kullanilan antijenlere göre farklı nesil testler olarak piyasaya sürülmüstürr ${ }^{[24]}$. Bu testlerin en önemli avantaj1 farklı rekombinant $\mathrm{HCV}$ antijenlerinin her birine karșı olușan antikor düzeylerini ayrı ayrı ölçebilmesidir ${ }^{[17]}$. Birinci nesil RIBA testleri, ELI-
SA'da kullanılanlar ile aynı antijeni ve bir bașka ek antijeni kullanır. İkinci nesil RIBA testlerinde ise iki farklı antijen kullanılmıștır ${ }^{[24]}$. Özgüllükleri ELISA testlerine göre daha yüksek olan bu testlerin kullanımlarını kısıtlayan en önemli dezavantajları ise duyarlılıklarının göreceli olarak daha düșuik olmasıdır ${ }^{[17]}$. Ayrıca, ELISA testleri ile düsüuk titrede pozitif bulunan örneklerin önemli bir bölümü RIBA ile de süpheli (indeterminate) sonuc vermektedir ${ }^{[17]}$. Sonuc olarak, düsüuk pozitif anti-HCV test sonucu olan bir örnekte HCV-RIBA testinin pozitif çkması ile infeksiyon varl1ğı doğrulanır, HCV-RIBA sonucu da negatif ise anti-HCV sonucunun yanlıș-pozitif olma olasılığı cok yüksek seklinde değerlendirilir. Geleneksel bir yöntem olarak geçmiște doğrulama testi kullanılan RIBA testlerinin yerini günümüzde periferik kanda HCV-RNA varlığını göstermeye dayalı moleküler testler almıștır ${ }^{[8]}$.

\section{Kor Antijeninin Saptanması}

$\mathrm{HCV}$ proteinlerinin üretiminin viral replikasyonun bir göstergesi olması nedeniyle bu proteinlerin kan düzeylerinin ölçülmesi, doğrudan HCV-RNA düzeylerinin belirlendiği testlere bir alternatif olarak düșünülmüștür. $\mathrm{HCV}$ kor antijen testi, serum veya plazmada $\mathrm{HCV}$ proteinlerinin saptanması için tasarlanmıș ve ticari olarak piyasaya sürülmüștür ${ }^{[7,8]}$. CLIA bazlı kantitatif bir test olan Architect HCV Ag Testi (Abbott, Almanya) ve farklı HCV kor antijen testleri ile yapilan calıșmalar, kor antijeni düzeylerinin ölçülmesinin HCV-RNA seviyelerinin belirlenmesi gibi hassas ya da kesin sonuçlar sunmadığını, ancak kor antijeni seviyelerinin HCV-RNA düzeyleriyle önemli ölçüde ilișkili olduğunu göstermiștir ${ }^{[8,11]}$. NAT yaklașımlarından daha hızlı ve genellikle daha ucuz olduğu için, HCV kor antijeni testinin özellikle ekonomik kaynakların kısıtlı olduğu bölgelerde aktif infeksiyonu olan kișileri tanımlamada tercih edilebileceği öngörülmektedir ${ }^{[8]}$.

\section{MOLEKÜLER TANI YÖNTEMLERI}

HCV-RNA testleri tanıda kullanılan en duyarl yöntemlerdir ve altın standart olarak kabul edilir ${ }^{[16]}$. Moleküler tanı yöntemlerinin serolojik testlere en önemli üstünlüklerinden biri akut infeksiyon varlığını viral bulaștan 7-10 gün sonra (pre-serokonversiyon pencere dönemi) tespit edebilmeleri- 
dir, serolojik testlerde bu süre dört haftadan 8-10 haftaya kadar uzayabilmektedir ${ }^{[7,11,19]}$. HCV-RNA testleri ayrıca, anti-HCV pozitif hastalarda doğrulayıcı tanıda, tedavi yanitının izlenmesinde ve "HIV infeksiyonu ve kronik hemodiyaliz hastaları gibi" antikor üretiminin yetersiz olduğu durumlarda infeksiyon tanısında kullanılır ${ }^{[7,16]}$. HCV ile infekte annelerden doğan yenidoğanlarda infeksiyon tanıs1, organ transplantasyonundan sonra reinfeksiyon tanısı, organa özgü tanı ve değerlendirmeye imkan vermesi, genotip tayini ve virüs kantitasyonu moleküler testlerin diğer önemli üstünlükleridir ${ }^{[7]}$.

Moleküler tanı testleri için örnekleme uygun malzemeler kullanılarak yapılmalıdır. Stabilitesi zayif bir molekül olan RNA bütünlüğuinün korunması için kan örneğinin uygun kosullarda transportu sağlanmalı ve en kısa süre içerisinde laboratuvara ulasstırılmalıdır. Kan alındıktan sonraki altı saat içinde laboratuvara ulașamayacaksa plazma (veya serum) nükleaz içermeyen bir tüpe alınmalıdır. Preanalitik süreçteki hatalar yanlıș-negatif test sonuçlarına neden olabildiği gibi, infekte kișilerin serum ve plazmalarında HCV-RNA varlığının saptanamadığı özel durumlar da vardır. Kronik hepatit C'nin patolojik formlarından biri de, plazma örneklerinde saptanabilir duizeyde HCV-RNA bulunmadığı halde, periferik kan mononükleer hücreleri (PBMC) ve karaciğer biyopsi örneklerinin HCV-RNA pozitif olduğu okült HCV infeksiyonudur ${ }^{[25]}$. Benzer sekilde tedavi bitiminde hasta serumunda HCV-RNA yokluğu gelecekteki viremiyi dıșlamak için yeterli değildir, bu kișiler hala infeksiyon kaynağı olabileceğinden dolayı tedaviye yanıtının doğrulanması için PBMC'nin HCV-RNA için test edilmesi önerilmektedir ${ }^{[26]}$.

\section{Kalitatif HCV-RNA Testleri}

HCV-RNA testleri kalitatif ve kantitatif testler olarak tasarlanmıștır. Kalitatif HCV-RNA testleri klasik polimeraz zincir reaksiyonu (PCR), real-time PCR (RT-PCR) ya da "transcription mediated amplification (TMA)" tekniğine dayalı testleri içerir ${ }^{[19]}$. Geçmiște rutin tanı laboratuvarlarında kalitatif testler için saptama limitinin en az 50 $\mathrm{IU} / \mathrm{mL}$ olması gerektiği belirtilirken, günümüzde bu değer $25 \mathrm{IU} / \mathrm{mL}$ 'ye cekilmiș, hatta $15 \mathrm{IU} / \mathrm{mL}$ olmasının ideal olduğu belirtilmiștir ${ }^{[27]}$. Kalitatif testlerin tüm genotipler için eșit duyarlılıkta olması ayrıca önemlidir. Akut infeksiyon durumunda
HCV-RNA varlığı kalitatif RT-PCR ile coğunlukla ilk haftada doğrulanabilmektedir. HCV genomunun 5' kodlamayan bölgesi (5'UTR) nispeten yüksek korunmuşluğuna bağlı olarak, kalitatif PCR testlerinde tercih edilen bir gen bölgesi olmustur. Testin duyarlılığı ve özgüllüğünü gelistirme adına nested-PCR tasarımları da yapılmıștır ${ }^{[7]}$.

HCV-RNA'nın saptanması için ilk standardize RT-PCR testi olan Amplicor HCV (Roche, ABD) 1993 yılında kullanıma sunulmustur. Bu sistemde, uygun tampon kosulları altında ters transkriptaz ve yanı sira DNA polimeraz aktivitesine sahip olan Thermus thermophilus DNA polimerazı kullanılmıstır ${ }^{[7]}$. $\mathrm{Bu}$ birinci versiyon testin analitik (saptama) duyarlılığı 1000 RNA kopya/mL idi ve duyarlılık genotip bağımlıdı; test genotip 2 ve 3 izolatlarını, genotip 1'e kıyasla daha düșük duyarlılıkta saptayabiliyordu. İkinci versiyon testlerde tüm genotipler için aynı derecede duyarlılık olmak üzere, analitik duyarlılık 100 kopya/mL'ye kadar yükselmiștir ${ }^{[7]}$. Günümüzde rutin tanı laboratuvarlarında saptama duyarlılıkları cok daha üstün olan (10-25 IU/mL) ve aynı zamanda kantitatif sonuc verebilen moleküler testler tercih edilmektedir ${ }^{[27]}$.

HCV-RNA temelli diğer kalitatif testler arasında "ligase chain reaction (LCR)", TMA ve "nucleic acid sequence based amplification (NASBA)" temelli yöntemler de denenmiștir ${ }^{[7,8]}$. LCR oldukça uygun ve kullanıșlı görünse de, en önemli dezavantajı düșük özgüllüğuidür. Bu nedenle LCR'ye dayalı HCV-RNA tespit sistemlerinin gelișimi duraksamıștır ${ }^{[7]}$. TMA'nın analitik duyarlılığı, 25 ve 50 kopya/mL'de sirasıyla \%93 ve \%100'dür. Dünya Sağllk Örgütüne göre bu yöntemin HCV-RNA standart duyarlılığı \%96 (5 IU/mL) ve \%100 (10 $\mathrm{IU} / \mathrm{mL}$ )'dür. Bu testin $\mathrm{HCV}$ genotipleri (genotip 1a/b, 2b/c, 3a, 4c/d ve 6a) için karșlaștırılabilir etkinlikte sonuçlar sunduğu ve klinik özgülliuğuinün \%99.5'ten fazla olduğu bildirilmiștir ${ }^{[7]}$.

\section{Kantitatif HCV-RNA Testleri}

Geçmiște HCV infeksiyonunun primer tan1sında daha duyarlı olduğu için kalitatif testler tercih edilmiș, tedavi bașlangıcında ve takibinde ise kantitatif testler kullanılmıștır. Günümüzde kalitatif PCR testlerinin yerini duyarlılığı \%99, özgüllüğü \%98-99'lara ulașan kantitatif PCR testleri almıstır $^{[11]}$. Kantitatif HCV-RNA testleri infeksiyon 
tanısı, tedavi endikasyonu, tedavi süresine ilișkin kararların yönlendirilmesinde ve kalıcı viral yanıt oranlarının optimize edilmesinde kullanılmakta$\operatorname{dir}^{[7,8]}$. HCV-RNA düzeylerinin kantitatif tayini ile antiviral etkinlik kontrol edilirken, diğer taraftan potansiyel antiviral direnç gelișimi erken așamada tespit edilebilmekte ve daha uygun tedavi seçeneklerine gecilebilmektedir ${ }^{[7]}$. Duyarlı bir testin kantitasyon alt sinırının $25 \mathrm{IU} / \mathrm{mL}$ olması istenir. Günümüzde cok sayıda ticari kantitatif HCV-RNA testi kullanıma sunulmustur. "Roche High Pure system/Cobas TaqMan assay (Roche Molecular Systems), Versant HCV $1.0 \mathrm{kPCR}$ (Siemens), RealTime HCV (Abbott), Artus HCV QS-RGQ (Qiagen), Aptima HCV Quant Dx Assay (Hologic), Xpert HCV Viral Load (Cepheid)" bunlardan bazılarıdır ${ }^{[27]}$. Bu testlerin saptama duyarlılıkları 4-20 IU/mL ve kantitasyon alt limitleri 10-25 IU/mL aralığında değișir [27].

Dallı (branched)-DNA teknolojisi (Bayer Diagnostics), serum ve plazmada HCV-RNA'sının doğrudan kantitasyonu için geliștirilmiş sandviç nükleik asit hibridizasyon prosedürune dayalı bir sinyal amplifikasyon yöntemidir ve PCR temelli testlere alternatif bir yöntem olarak sunulmustur ${ }^{[7,28]}$. Quantiplex2 HCV-RNA 1.0 (Bayer Diagnostics) ile kronik infekte kișilerin \%80-90'1 ve testin ikinci versiyonu ile 95'inden fazlası (antiviral tedavi olmadan) saptanabilmekteydi. Versiyon 1 sadece $350.000 \mathrm{kopya} / \mathrm{mL}$ saptama limiti sunarken, versiyon 2 ile 200.000 kopya/mL serum duyarlılığına ulașılmıștır. Dallanmış zincir DNA testi 2.0 ve sonraki tüm sürümleri, tüm genotipler için esdeğer etkinlikle kantitasyon yapabilmektedir. Benzer prensiple çalısan bir bașka ticari test olan Versant2 HCV-RNA (bDNA 3.0, Bayer Diagnostics) ile 1000-2000 kopya/mL (615 IU/mL) alt saptama limiti ve numune seyreltme gerekmeksizin genis doğrusal dinamik aralık $\left(<2 \times 10^{3}-40\right.$ x $10^{6}$ kopya/mL) elde edilmistir ${ }^{[7,28]}$.

\section{HCV Genotip ve}

\section{Subtip Tanımlama Yöntemleri}

Antiviral tedavideki ilerlemelerle birlikte $\mathrm{HCV}$ ile infekte kișiler için tedavi bașarısı \%95'lerin üzerine cıkmıștır, bununla beraber HCV'nin yüksek genetik değișkenliği bașarı oranlarını olumsuz yönde etkilemeye devam etmektedir ${ }^{[29]}$. Tanisal güclüklere yol açan bu genetik ceșitlilik dolașımda- ki genotip-subtip sirkülasyonu, coklu infeksiyonlar, rekombinant formlar ve ilaca direncli ceșitli varyantların varlığı ile ilișkilidir ${ }^{[30]}$. Tedavi süresinin belirlenmesinde yol gösteren ve kalıcı viral yanıtın en güclui göstergesi olarak kabul edilen tedavi öncesi HCV genotipinin belirlenmesi HCV infeksiyonlarının yönetiminde en önemli basamaklardan biridir $^{[31]}$. Yeni HCV tedavilerinin, belirli hastalara uygun ilac kombinasyonları ve bu kombinasyonların kullanılma süreleri de dahil olmak üzere, tedavi cevabının kritik bir belirleyicisi olan HCV genotipine göre değișen spesifik endikasyonları vardir ${ }^{[8]}$. HCV genotip ve alt tiplerinin yanlıs tanımlanması, uygun olmayan bir tedavi rejiminin uygulanmasına ve ardından tedavi bașarısızlığına neden olabildiğinden, genotip ve subtip tayininin doğru olarak yapılması önem kazanmıștır ${ }^{[30]}$. Genotip dağılımı coğrafi bölgelere ve intravenöz ilaç kullanıcıları (intravenous-drug users, IVDU) gibi popülasyondaki spesifik gruplara göre değișkenlik gösterir ${ }^{[3,8]}$. Örneğin; direkt etkili antiviral ilaçlar (DAA) ile tedaviye göreceli olarak daha dirençli olması nedeniyle epidemiyolojik önem tassıan genotip 3'ün yayılması, 3a alt tipinin IVDU arasındaki görülme sıklığı ve Hindistan ve Pakistan gibi alt tip 3a'nın baskın olduğu ülkelerden nüfus göcui ile ilișkilendirilmiștir ${ }^{[3,8,25]}$

Bugün dizi analizi sonuclarına göre \%30-35'in üzerinde nükleotit dizi farklılığı olan yedi $\mathrm{HCV}$ genotipi tanımlanmıștır ${ }^{[3,32]}$. Bu gruplar arasında ek alt tipler de (subtip a, b, c ve diğerleri; 67 konfirme ve 20 geçici sub tip) tanımlanmıstır ${ }^{[3,7,32]}$. Alt tiplerin homolojisi \%80 ila \%90 arasında değișir. Daha küçük dizi tutarsılıklarına bașka bir tanım verilmemekte ve $\mathrm{HCV}$ türümsüleri (quasispecies) olarak ele alınmaktadır ${ }^{[7]}$. Dünya genelinde en sı rastlanan genotip \%46.2'lik oran ile genotip 1 'dir ${ }^{[9]}$. Ülkemizde yapılan calıșmalarda ise en sik genotip $1 \mathrm{~b}$ saptanmaktadir [33]

HCV genotip tayini klasik PCR amplifikasyonunu takiben serit bazlı ters hibridizasyon (LIPA, line probe assay) ve dizi analizi yöntemleri ile yapılabilmekte veya RT-PCR ile doğrudan tanımlanabilmektedir ${ }^{[8,19]}$. HCV genotip tayininde genotip spesifik floresans rezonans enerji problarının (FRET) kullanılması, primer-spesifik ekstensiyon, erime eğrisi analizi, PCR-RFLP (restriction fragment length polymorphism), heterodupleks mobi- 
lite analizi ve sivı mikroarray (xMAP Luminex) gibi kendine has avantajları ve sınırlamaları olan ceșitli yöntemler de kullanılmaktadır ${ }^{[8,19,25]}$. Genotip tayini için çok sayıda farklı teknik kullanılmasına rağmen $\mathrm{HCV}$ izolatlarının yeni nesil dizi analizi günümüzde altın standart yaklasıım olarak görülmektedir ${ }^{[7]}$. HCV genotip tanımlamalarında sekans bazlı yöntemler ile sekans bazlı olmayan ticari testler karșılaștıııldığında yanlıs tanımlama oranlarının kullanılan ticari testlere göre değișmek üzere \%2 ila \%10 aralı̆̆ında olduğu bildirilmiştir ${ }^{[34]}$. Standart Sanger dizi analizi zaman alıcı ve emek-yoğun olmasının yanında, sonuçlarının standart olmaması, sadece baskın olan dizinin okunabilmesi, \%15-20'den daha az oranda bulunan varyantları saptayamaması ve coklu genotip infeksiyonlarını ayırt etmedeki yetersizliği gibi dezavantajları nedeniyle rutin analizler için önemini kaybetmeye bașlamıștır ${ }^{[8,32]}$. Sirasıyla 2005 ve 2011 yllları itibariyle kullanılmaya bașlayan ikinci ve üçüncü nesil dizi analizi teknikleri $\% 1$ ya da daha az sıklikta bulunan varyantları ve dirençli mutantları saptayabilmeleri ile sik tercih edilen güclü analiz yöntemleri olarak öne clkmıștır ${ }^{[30,32]}$. Bununla beraber, \%1 varyantların saptanabilmesi için cok sayılda okuma yapilması gerekmekte ve bu durum ciddi maliyet artısına neden olmaktadir. Naif bireylerde \%1 varyant saptamanın klinik önemi belirsizdir ve mevcut rehberler antiviral tedavi rejimlerini secerken sadece majör varyantların (> \%15) dikkate alınması gerektiği belirtilmekte$\mathrm{dir}^{[35]}$. Bu nedenle birçok laboratuvar yeni nesil dizi analizi sistemlerini Sanger esiğinde kullanmaktadır. Yeni nesil dizi analizinin tedavi öncesi analizlerden ziyade tedavi süresi icinde bașarısılıklarda kullanılması önerilmektedir ${ }^{[35]}$. Ion Torrent (Thermo Fisher Scientific, Waltham, MA) pirosekanslama, Illumina MiSeq (Illumina, San Diego, CA), HiSeq (lllumina, San Diego, CA) ve NexSeq (Illumina, San Diego, CA) platformları ikinci nesil testlerin yaygın kullanilan örnekleri iken, PacBio (Pacific Biosciences, Menlo Park, CA) ve MinION (Oxford Nanopore Technologies, Oxford, UK) yöntemleri ise 2011 ve sonrasında kullanıma sunulan üçüncü nesil dizi analizi yöntemleridir ${ }^{[30]}$.

Primer bağlanma bölgelerindeki varyasyonlar nedeniyle PCR ve dizi analizi testleri sekteye uğrayabilmektedir. Bu sorunu așabilmek için bir- çok ticari kit iyi korunmus genomik bölgelerden biri olan 5'UTR bölgesini hedefleyecek sekilde tasarlanmıștır ${ }^{[19]}$. 5'UTR bölgesi yüksek düzeyde korunmus olmasına rağmen seçilecek hedef bölgenin uzunluğu 200 bp'den kısa olmamak koşuluyla genotip düzeyinde tanımlama için genel olarak iyi sonuçlar vermektedir ${ }^{[36]}$. Genel olarak kısa diziler için kullanilan sekanslama yöntemleri daha cok 5'UTR bölgesi için tasarlanmıstır. TruGene 5'UTR $\mathrm{HCV}$ Genotyping (Siemens, Almanya) yöntemi bunlardan biridir ve 5'UTR bölgesinin sekans karșlaștırması prensibiyle çalıșır, ancak bu yöntem subtip identifikasyonunda yetersiz kalmaktadır ${ }^{[19]}$. 5'UTR bölgesi dizi analizinin genotiplendirme (örneğin genotip 1 ve 4 ayrımı) ve subtiplendirme için yetersiz kalabilmesi (örneğin genotip $1 \mathrm{a}$ ve $1 \mathrm{~b}$ ayrımı) nedeniyle kodlanan bölgelerin de (NS5B bölgesi ve kor/E1 gibi) de hedef olarak eklenmesi önerilmektedir ${ }^{[7,36,37]}$. Buna uygun olarak TruGene2 HCV NS5B (Visible Genetics) yöntemine subtiplendirme için NS5B geninin dizilenmesi eklenmiștir ${ }^{[7]}$.

Genotip analizinde bir bașka yaklașım RTPCR yöntemidir. Real-time HCV genotype II kiti (Abbott) genotip spesifik "floresan ișaretli oligonükleotitler" kullanılarak altı farklı genotipin ve $1 \mathrm{a}$ ve $1 \mathrm{~b}$ alt tiplerini saptayabilmektedir ${ }^{[38]}$. Bu test üç farklı primer seti içerir. Bu primer setlerinden biri 5'UTR bölgesini (tüm HCV'leri), diğeri genotip 1a'nın NS5B bölgesini ve üçüncü primer seti de genotip 1b'nin NS5B bölgesini amplifiye edecek sekilde tasarlanmıstır.

LIPA yöntemi serit (strip) temelli ters hibridizasyon prensibine dayalı bir test olup PCR ile amplifikasyonu takiben elde edilen ürünlerin genotip spesifik problar ile hibridizasyonunu esas allr ${ }^{[38]}$. Katı faz striplere tutunan PCR amplikonlarının kolorimetrik (biotin-streptavidin) bir dedektör arac1lığılla saptanmasını içerir. LIPA testleri ucuzdur, ancak manuel olarak yapilır ve emek-yoğundur ve sonuçların yorumlanması daha subjektiftir ${ }^{[8]}$. Birinci nesil LIPA testlerinde primerler 5'UTR bölgesini hedefleyecek sekilde tasarlanmısken, ikinci nesil testler 5'UTR bölgesi ile beraber kor bölgesini de hedeflemektedir. Versant HCV genotipleme testi rutin tanı laboratuvarları için geliștirilen ve 5'UTR bölgesini hedefleyen LIPA temelli ticari bir testtir ${ }^{[19]}$. Real time HCV Genotype II (Abbott) 
ile karșılaștırıldığında Versant LiPA HCV 2.0 (Siemens, Almanya) testinin genotipleme için \%99.2 ve alt tiplendirme için \%96.1'lik bir uyum oranına sahip olduğu gösterilmiștir ${ }^{[38]}$. Inno LIPA II (Innogenetics, Belçika) yönteminde ise HCV-RNA ekstraksiyonundan ve transkripsiyonundan sonra biyotiplenmiș primerler kullanilarak 5'UTR bölgesinin bir fragmanı için cDNA'nın amplifikasyonu gerçekleștirilir. Daha sonra PCR ürünü, nitroselüloz membrana tutturulmus oligonükleotitlere (ters) hibridize edilir. Bu test, HCV 1-6 genotiplerinin tanımlanmasına imkan verir ve kullanımı oldukca kolaydır. 5'UTR dizisi nedeniyle HCV-1a ve HCV-1b alt tipleri arasındaki farkllassma özgünlüğü \%90'a ulassır. Test HCV-2a ve HCV-2c alt tiplerini ise güçlü bir sekilde ayırt edemez ${ }^{[7]}$.

Sorin Biomedica tarafından geliștirilen DNA enzim immünoassay (PCR-EIA) yöntemi kor bölgesini hedefleyen ve PCR sonrasi ters hibridizasyon yapılmasına dayalı bir ELISA testidir. Yüksek duyarllığı olan bu yöntem ile hem genotiplendirme hem de subtiplendirme yapilabilmektedir. Ilk olarak HCV-RNA ekstrakte ve ters transkribe edilir, daha sonra bir cekirdek bölgesi dizisi "nested PCR" ile amplifiye edilir. PCR ürünü, bir membrana tutunan genotip spesifik oligonükleotitler tarafından hibridize edilir. Sonunda cift sarmallı DNA'ya bağlanabilen monoklonal antikorlar bu cDNA-DNA hibridlerini saptar. Kor bölgesi $\mathrm{HCV}$ genotipleri ve alt tipleri için ( $\mathrm{HCV}-4,5$ ve 6 genotipleri de dahil olmak üzere) cok yüksek özgünlükte diziler içerir ${ }^{[7]}$.

\section{Çoklu Genotiplerin ve}

\section{Rekombinant Susların Tanımlanması}

HCV infeksiyonlu olgularda coklu HCV genotipleri ve alt tipleri ile infekte olmus bireylerdeki popülasyon heterojenitesi de dikkate alınmalıdır. Örneğin; en yaygın genomik varyanta yönelik bir tedavi rejiminin uygulanması, tanımlanamayan varyantların ortaya cıkması için bir fırsat sağlayacaktır ${ }^{[30]}$. Genel popülasyonda, coklu genotip infeksiyonlarının tüm $\mathrm{HCV}$ pozitif hastalarda \%210 oranında olduğu tahmin edilmekte iken, bu oranın riskli popülasyonlarda cok daha yüksek olduğu bildirilmektedir ${ }^{[39,40]}$. Coklu infeksiyonların tespit oranı kullanılan metodolojiye ve coğrafi bölgeye göre önemli ölçüde değișkenlik gösterdiğinden dolayı bu infeksiyonların gerçek prevalan- sını belirlemek güçtür ${ }^{[39]}$. Türkiye'de yapılan ve 23 merkezden 17.578 hepatit $C$ hastasının dahil edildiği bir çalıșmada 223 (\%1.3) hastada karıșı genotip varlığı belirlenmiş ve en yaygın karıșık genotip kombinasyonları $1 \mathrm{~b}+4(\% 0.83)$ ve $1 \mathrm{a}$ $+1 \mathrm{~b}(\% 0.26)$ olarak bulunmustur (41). Coklu tip varlığının DAA tedavisi üzerindeki etkisinin minimal düzeyde olabileceğini öne süren calıșmalar olmakla beraber, bu durumun klinik öneminin ortaya konması için ileri calıșmalara gereksinim duyulmaktadır ${ }^{[41,42]}$. Çoklu genotip varlığının tanımlanmasında genotip spesifik PCR ve yeni nesil dizileme teknikleri kullanılmaktadır ${ }^{[43]}$. PCR temelli yaklașımlarla yanlıs tanımlamalar yapılabilirken, random primer ve probe zenginlestirme temelli derin (deep) dizileme yöntemleri ile daha bașarılı sonuçar alınmıștır ${ }^{[39,40]}$. Sanger dizilemede ise baskın genotip saptanmakta ve bu yöntemle coklu tip görülen (mixed) infeksiyonlar veya rekombinant varyantların tanımlanması mümkün olmamaktadir ${ }^{[30]}$. Upstream PCR ve klonlama stratejilerinin birlikte uygulanmasını içeren klonal dizileme de tek bir bireyde dolașan tüm viral varyantları saptamada yetersiz kalabilmektedir ${ }^{[30]}$

$\mathrm{HCV}$ infeksiyonlarının tanısında güclüklere neden olan bir diğer faktör olan rekombinasyonun HCV için genel olarak nadir görülen bir olay olduğu düşuinülmektedir. Bununla birlikte, bu olgunun, mevcut genotipleme stratejilerindeki kistlamalar gibi farklı engeller nedeniyle hafife alındığ düșünülmektedir ${ }^{[30]}$. Rekombinant sușların ortaya çııșına katkıda bulunan faktörlerden biri, bir coğrafi bölgede birden fazla $\mathrm{HCV}$ genotipinin veya alt tipinin birlikte dolașımıdır. Bireylerde coklu veya ardısılk infeksiyonlar sırasında sitoplazmanın ayrı bölgelerinde coğalan coğul genlerin birlikte yerleșimi genom hibridizasyonu için ön kosuldur ${ }^{[30]}$. Ticari genotip testlerinin ve amplikon bazlı Sanger dizileme yaklașımları doğası gereği, sıklıkla HCV genomunun sadece bir veya iki korunmus bölgesini hedef alır ve bu nedenle, rekombinant virüslerin varlığı gözden kaçabilir. Yeni nesil dizi analizi platformlarının rekombinant formların tanımlanmasında geleneksel uygulamalara kiyasla daha güvenilir olduğu gösterilmiștir ${ }^{[30]}$. Bugüne kadar, HCV infeksiyonlu bireylerde en az sekiz genotip ve dokuz alt tip rekombinant tanımlanmıștır. Yapılan calıșmalarda genotip $2 \mathrm{k} / 1 \mathrm{~b}$ popülasyonlarının ve 
olgu bazlı genotip $2 / 5,2 \mathrm{~b} / 1 \mathrm{~b}, 2 \mathrm{~b} / 1 \mathrm{a}$ ve $2 \mathrm{i} / 6 \mathrm{p}$ rekombinantlarının varlığı gösterilmiștir ${ }^{[32]}$. HCV rekombinasyonunun klinik önemi, bu sușların antiviral tedavi bașarısızlığına yol açan yanlıș tanı ile doğal tip olarak sınıflandırılmasıdır. Örneğin en sık saptanan rekombinant form olan CRF_2k/1b'nin hatalı bir sekilde HCV genotip 2 olarak siniflandırılmasının, yanlıs antiviral tedavi seçimine neden olabileceği ve viral kür oranının \%27'ye kadar düșmesine neden olabileceği bildirilmiștir ${ }^{[30]}$.

\section{Tuiruimsii Analizleri}

Kronik HCV infeksiyonundaki viral popülasyon, türümsüler (yarı-türler) olarak bilinen ve yakından ilișkili viriyonların heterojen bir karıșımından olușur. Türümsü popülasyonunun ceșitliliğinin (tedaviden bağımsız olarak) karaciğer hastalığına doğal ilerlemeyle ilișkili olduğu bulunmuștur. Yüksek türümsü çeșitliliği hepatit $\mathrm{C}$ viriyonlarının hızlı replikasyon oranı, HCV'nin RNA bağımlı RNA polimerazının sınırlı transkripsiyon duyarlılığı ve konak immün yanıtının olușturduğu baskıdan kaynaklanabilir ${ }^{[7]}$. Türümsü izolatların klasik klonlanması ve dizilenmesi, rutin klinik tanı için fazla emek gerektiren bir uygulamadır ve henüz standardize edilmemistir. Hipervariable genom bölgelerinin (1470-1550 bazlar arası) klonlanması ve dizilenmesi, infekte olmuş bir kișide yarı-türlerin saptanması için tercih edilir. Hipervariable bölge PCR ürünlerinin tek sarmallı konformasyon polimorfizmi (SSCP) ve heterodupleks jel sapması analizinin virüsün kücuuk popülasyonlarını saptamak için yeterince duyarl olduğu bulunmuștur ${ }^{[7]}$.

\section{HCV Serotiplendirme Yöntemleri}

$\mathrm{HCV}$ tiplendirmesinde moleküler yöntemlerin dișında daha az duyarlı olan serotiplendirme yöntemleri de denenmiștir. NS4 veya kor bölgesi tarafından kodlanan epitoplar ile reaksiyona giren genotip spesifik antikorları hedefleyen serotipleme testleri bu yöntemlere örnek gösterilebilir ${ }^{[44,45]}$. NS4 proteininin epitop haritalaması, HCV antikorlarının iki ana antijenle etkileșime girdiğini ortaya koymaktadır. Birkaç genotipte, bu genom bölgeleri yüksek değișkenliğe sahiptir. Belirtilen bölgelerle uyumlu, genotip spesifik peptitlerin kullanılması ile serolojik genotipleme yapilabilmektedir. Serolojik HCV genotiplendirmesi hılı ve düsük maliyetlidir, ancak alt tipleri ayırt etmede bașarısızdır ${ }^{[7]}$.
RIBA Serotyping S1 Assay (Chiron) yöntemi kor ve NS4 antijenlerine karșı olușan antikorların saptanmasına dayalıdır. Rekombinan immünoblot tekniği ile calıșan bu yöntem ile genotiplendirme yapilabilirken subtiplendirme yapilamamaktadir ${ }^{[7]}$. Anti-NS4-Serotyping (Murex HCV Serotyping 1-6, Abbott Diagnostics) tekniği ise NS4 bölgesinin saflaștırılmıs HCV antijeni ile kaplanmıs mikro titre plakalarına dayanır. Bu kit mevcut altı genotipten beșinin çözünür NS4 antijenleriyle birlikte hasta veya kontrol serumuyla inkübe edilir. Antijen-antikor kompleksi, peroksidaz isaretli ikinci bir antikor vasıtasıla ve bir kromojenik substratın nihai ilavesi ile saptanır. Bu sistem örneklerin \%90'ından fazlasında, $\mathrm{HCV}-1,2$ ve 3 genotiplerinin yanı sıra HCV-4'ü kesin olarak tanımlayabilmektedir. Üreticiye göre HCV-5 ve HCV-6 genotip karakterizasyonu da mümkündür ${ }^{[7]}$.

\section{Antiviral Direnç Testleri}

Günümüzde antiviral direnç izlemi HCV tanı ve tedavi yönetimin bir parçası haline gelmiștir. Antiviral tedavi sirasında viral replikasyonun etkili bir sekilde durdurulamaması halinde, seçici tedavi baskısı direnc ilișkili varyantların birikmesine ve antiviral tedavinin bașarısız olmasına yol açar (30). Bazı araștırma grupları uygun tedavi protokolünün seçimi için tedavi öncesi $\mathrm{HCV}$ direncinin arașt1rılmasının önemini vurgulasa da, güncel rehberler her hasta için tedavi öncesi test yapilmasını önermemektedir ${ }^{[46]}$. Tedavi öncesi HCV bazal ilaç direnç testi sadece iki durumda önerilmektedir. Birincisi NS3 varyantı Q80K varlığının belirlenmesi, ikincisi ise HCV1a infeksiyonlarında elbasvir direncinin araștırılmasıdır ${ }^{[30]}$. Antiviral direnç testleri daha cok tedavi yanıtsızlığı ve relaps durumlarında yapılmaktadır. Onaylanmıș ilaçlarda $\mathrm{HCV}$ direncinin araștırılması için standardize edilmiș ticari testler bulunmadığından, günümüzde direnç testleri coğunlukla popülasyon dizilemesi (Sanger) veya yeni nesil derin dizilemeye dayalı kullanıcı tasarımlı tekniklerle yapılmaktadır ${ }^{[46]}$. HCV antiviral direnç analizi için fenotipik direnç testleri, popülasyon bazlı sekanslama, klonal sekanslama, spesifik hedeflerin analizleri gibi farklı yaklașımlar uygulanmakla beraber, günümüzde maliyet, is yükü-test süresi, duyarlllı ve veri üretim kapasitesi gibi parametrelerde öne çkan yeni nesil dizileme teknikleri antiviral direnç analizleri için en uygun 
tanısal araçar haline gelmiștir ${ }^{[30,47]}$. Yeni nesil dizi analizi prensibine dayalı Sentosa SQ HCV genotipleme testi (Vela Diagnostics, Singapore) NS3, NS5A ve NS5B gen bölgelerini hedef alır ve viral genotipleme ve ilac direnci analizi için lisans alan ilk testtir ${ }^{[30,48]}$.

\section{DÏĞER TANI YÖNTEMLERi}

Hasta bașı hızlı test platformları (point-of-care test) klinikler ve potansiyel olarak hekim muayenehaneleri için tasarlanmıș olup, yaklașı iki saat içerisinde sonuc verebilmektedir. Bu yaklașım, merkez laboratuvarına gereksinimi azaltmıs olmakla birlikte, yine flebotomize numuneler ve önemli kaynak altyapısı gerektirir, bu da birçok ortamda eksiktir ${ }^{[8]}$. OraQuick HCV Rapid Test (OraSure Technologies) FDA tarafından kan örneklerinde $\mathrm{HCV}$ tanısı için onaylanmıștır ve $\mathrm{HCV}$ salgın algoritmalarında kullanılabileceği belirtilmiștir ${ }^{[49]}$. Chembio DPP HCV TEST (Chembio Diagnostics, ABD), Multiplo Rapid HIV/HCV Antibody Test (MedMira Lab Inc., Kanada) ve Toyo anti-HCV test (Turklab, İzmir, Türkiye) gibi cok sayıda ticari hızlı test geliștirilmiștir, bu testlerin coğunluğu tam kan veya serum örneklerinde antikor saptamak üzere tasarlanmıs olup sonuç verme süreleri genel olarak 3 ila 40 dakika arasında değișmektedir ${ }^{[50]}$.

$\mathrm{HCV}$ infeksiyonlarında gen polimorfizminin tedavi sonuçları üzerine etkileri doğrudan HCV tanısı ile ilgili olmamakla beraber, ayrı bir konu olarak çalıșılmıștır. IL-28B, paraoksonaz-1 (L/ M55 ve Q/R192), haptoglobin ve cok sayıda farklı hedefler araștırılmıștır [51,52]

\section{OLGU YÖNETIMi ve ALGORITMIK TANI}

HCV infeksiyonlarının tanı algoritmasında ilk bulas veya süpheli maruziyet sonrası erken tanı, infeksiyonun evreleri ve kroniklesme-temizlenme durumunun ortaya konması, antikor üretiminin düșük düzeylerde olduğu spesifik hasta gruplarına yaklașım ve serolojik testler ile elde edilen düsük-süpheli pozitif örneklerde test tekrarı süreleri ve doğrulama testleri gibi önemli başlıklar karșımıza çkar. HCV infeksiyonlarının tanısında geçirilmiș infeksiyon ve tedavi ile iyileșmiș infeksiyonların kronik infekte kișilerden ayırt edilmesi de önem arz etmektedir ${ }^{[8]}$

\section{Akut HCV İnfeksiyonu ve İyileșme}

Tüm akut HCV infeksiyonlarının (asemptomatik veya semptomatik) \%70-85'i kronikleșirken \%15-30'u ilk maruziyetten sonraki 6-12 ay içerisinde tedavi edilmeden temizlenmekte ve infeksiyon kalıcı sekel birakmaksızın tamamen iyilesmektedir ${ }^{[8,10,19]}$. Tedavisiz olarak iyilesen veya antiviral tedavi ile iyileșen kișilerde anti-HCV antikoru pozitif olarak kalırken, saptanabilir bir viremi gözlenmemektedir ${ }^{[8]}$. İnfeksiyon bulașını takiben 4-10. haftalardan itibaren anti-HCV pozitifliği gösterilebilir, ancak bu süre 24. hafta sonuna kadar uzayabilir. Bulas sonrası hasta kanında HCV-RNA varlığı ise 1-2. haftalardan itibaren saptanabilir düzeydedir. HCV maruziyetinden 2-8 hafta sonra yükselmeye bașlayan serum aminotransferaz seviyeleri 8-12 hafta kadar normal sınırların üzerinde seyredebilir (maruziyet sonrası 24. haftaya kadar). Akut semptomatik HCV infeksiyonlarında karaciğer enzimleri (özellikle ALT; alanin aminotransferaz) $200 \mathrm{IU} / \mathrm{mL}$ veya daha yüksek değerlere ulașabilir. Transaminazların en yüksek düzeylere ulașmasından sonra HCV-RNA seviyesinde dikkat çekici bir düșme görülür. Akut HCV infeksiyonlarının \%15-30'unda görülen semptomlar genellikle maruziyetten 6-7 hafta sonra görülür, bununla beraber bu aralık 2-26 haftaya kadar geniș olabilir. Bu semptomlar karaciğer enzim yüksekliğinin devam ettiği sürece gözlenebilir. İyileșme ve viral klerens durumunda 24-26. haftalarda serum ALT değeri normal düzeylere döner ve anti-HCV değerlerinin yükselmesi ile beraber HCV-RNA saptanabilir duizeylerin altına iner (Şekil 1) ${ }^{[10,53]}$.

\section{HCV Persistansı ve Kronik İnfeksiyon}

Kronik infeksiyonlarda anti-HCV kalıcı olarak pozitiftir, aynı zamanda HCV-RNA pozitifliği de persiste olur. ALT düzeyleri inișli cıkıșl bir seyir gösterirken, yükselmesi karaciğer inflamasyonunun devam ettiğini gösterir. Bununla beraber kronik infeksiyonlardaki ALT yüksekliği akut infeksiyona göre daha düșük düzeylerdedir. Serum ALT düzeyleri hastalığın aktivite durumuna göre değismek üzere dönemsel yükselmeler gösterebilir veya normal olarak da saptanabilir ${ }^{[10,53]}$. HCV-RNA düzeyleri akut $\mathrm{HCV}$ infeksiyonlarında dalgalı bir seyir gösterebilir, ancak kronik HCV infeksiyonlarında HCV-RNA düzeylerinin seyri daha stabildir 


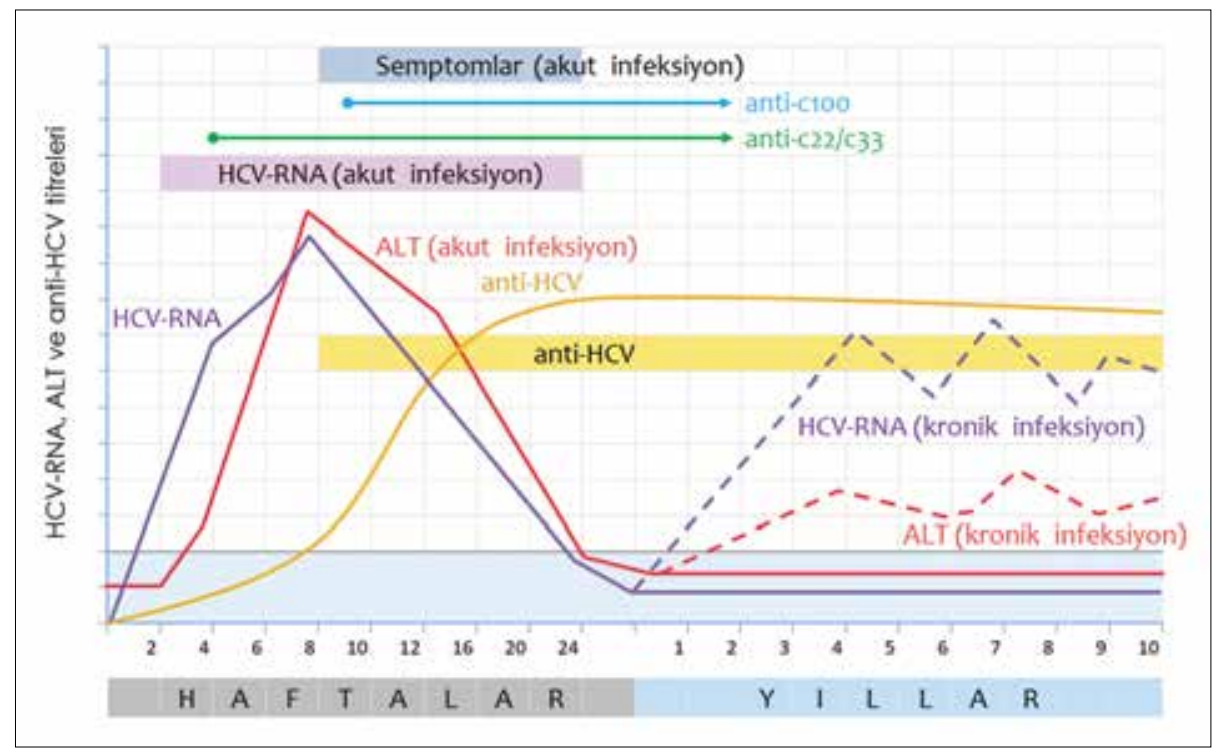

Şekil 1. Akut ve kronik HCV infeksiyonlarında klinik bulguların, karaciğer enzimi (ALT) ve viral belirteçlerin saptanma zamanları ve düzeylerindeki değişiklikler ${ }^{[7,10,18,53]}$.

ve genel olarak 1 log'dan fazla değisiklik görülmesi beklenmez ${ }^{[16]}$. Hafif klinik bulgularla seyreden kronik HCV olgularında, IgM antikorları nadiren bulunurken, agresif karaciğer hastalığı olan hastaların \%50'sinden fazlasında IgM varlı̆̆ı saptanabilmektedir. IgG antikorları ise kronik hepatitli hastalarda genellikle persiste olmaktadır. Kronik $\mathrm{HCV}$ infeksiyonunda, HCV antikorlarının varlığı kalıcı viremi (yani HCV-RNA pozitifliği) ile korelasyon gösterir. Sadece düșük $\mathrm{HCV}$ viral yükü ile bașvuran ihmal edilebilir sayıdaki kișide ise anti-HCV pozitifliği görülmeyebilir ${ }^{[7]}$.

\section{HCV İnfeksiyonlarının \\ Rutin Mikrobiyolojik Tanısı}

Normal koșullarda HCV infeksiyonlarının tanısı bir tarama testi olarak tanımlanabilen anti-HCV antikor testinin yapılmasıyla bașlar. Bu tür bir testin duyarllığının \%95, özgülllüğünün \%99, pozitif likelihood ratio değerinin \%95, negatif likelihood ratio değerinin 0.05 olması istenir, ki günümüzde bu sartları en iyi sağlayan testler ELISA ve CLIA temelli üçüncü ve dördüncü nesil testlerdir ${ }^{[6]}$. Bununla beraber, akut HCV infeksiyonu geciren kișilerde anti-HCV antikorlarının saptanma oranı ancak altınc1 ayın sonunda \%100'e ulașır. Bu nedenle bilinen ve süpheli maruziyeti olan hastalar da dahil olmak üzere HCV infeksiyonu süphesi olan kisiler bu oranlar dikkate alınarak takip edil- melidir [53]. Anti-HCV sonucu pozitif ise, mevcut infeksiyon HCV-RNA'nın kalitatif bir ölçümü ile teyit edilmelidir. Pozitif bir anti-HCV antikor test sonucu olan, ancak HCV-RNA test sonucu negatif olan hastalarda HCV infeksiyonu olmadığı düsüunülür, ancak yanlıs-negatif HCV-RNA testi olasıll$\breve{g ̆}_{1}$ unutulmamalıdır (Tablo 1) ${ }^{[6]}$. Bu nedenle, test edilen kișinin son altı ay içinde $\mathrm{HCV}$ maruziyeti olduğundan süpheleniliyorsa veya $\mathrm{HCV}$ hastalığına dair klinik kanitlar varsa HCV-RNA testi tekrarlanmalıdır ${ }^{[8]}$. Negatif bir anti-HCV antikor testi ile birlikte pozitif bir HCV-RNA testi varlı̆̆1 ise, akut $\mathrm{HCV}$ infeksiyonunun erken dönemine ișaret $e^{e d e r}{ }^{[6]}$. Son altı ay içinde HCV maruziyeti olan bir hastada anti-HCV antikor test sonucu negatif çıarsa, HCV-RNA'sı en az altı ay boyunca dört ila sekiz haftada bir ölçülmeli veya 12 hafta içinde anti-HCV antikor testleri tekrar edilmelidir ${ }^{[6]}$.

Anti-HCV ELISA testlerinde elde edilen düsuik pozitif (cut-off değerine yakın) sonuçlar rutin tanı laboratuvarlarında sık karssılașilan problemlerdendir ${ }^{[17]}$. Düsüuk pozitif anti-HCV test sonucu olan bir hasta (testlerin duyarll1kkları ayrı tutulmak kosulu ile) akut HCV infeksiyonunun erken dönemlerinde (pencere dönemi) olabileceği gibi, bu durum uzun zaman önce geçirilmis bir $\mathrm{HCV}$ infeksiyonu ile ilișkili düsüuk antikor düzeyleri ile ilgili de olabilir. Bu değerlerin coğunun yalan- 
Tablo 1. HCV infeksiyonlarının laboratuvar tanısında kullanılan test sonuçlarının yorumlanması ${ }^{[6-8,53]}$

\begin{tabular}{|c|c|c|c|}
\hline Anti-HCV & HCV-RNA & Süre & Yorumlar ve olasılıklar \\
\hline+ & + & $<6$ ay & - Akut HCV infeksiyonu \\
\hline+ & - & $>6$ ay & $\begin{array}{l}\text { - Geçirilmiş infeksiyon } \\
\text { - Tedavi ile iyileşme } \\
\text { - Yanlış-pozitif anti-HCV testi (genelde düşük titreli**) } \\
\text { - Yanlış-negatif HCV-RNA testi }\end{array}$ \\
\hline- & + & $<6$ ay & $\begin{array}{l}\text { - Akut HCV infeksiyonunun erken dönemi* } \\
\text { - Antikor cevabı oluşmayan immünsüpresif hasta } \\
\text { - Yanlış-pozitif HCV-RNA testi } \\
\text { - Yanlış-negatif anti-HCV testi }\end{array}$ \\
\hline
\end{tabular}

* Anti-HCV testinin daha sonraki 8- 12 hafta içerisinde serokonversiyon ile pozitif sonuç vermesi koşulu ile.

** S/Co değerinin 1'e yakın olması durumunu ifade eden düşük titreli pozitif test sonucu tanımı ticari testler için değişkenlik göstermektedir. Örneğin; CDC'ye göre S/Co değeri $\geq 11.0$ olduğunda test sonucunun $\% 95$ olasıllkkla gerçek pozitif olarak kabul edildiği CLIA temelli Advia Centaur XP testi için S/CO değerinin 1.15-6.15 arasında olması düşük titreli pozitif test sonucu olarak değerlendirilebilirken, ABBOTT HCV EIA 2.0 testi için S/Co değeri $\geq 3.8$ olarak bulunduğunda test sonucu \%95 olasılıkla gerçek pozitif olarak kabul edilir ${ }^{[17]}$. Türkiye'de yapılan ve Architect i2000SR (Abbott, ABD) ve LiaisonXL Murex (DiaSorin, i̇talya) platformlarının kullanıldığı bir çalışmada ise S/Co değeri 1.0-4.0 aralığında iken HCV-RNA pozitiflik oranı \%1.9 ve 7.1-10 aralığında \%37.1 ve $\geq 16.1$ iken \%75 olarak bulunmuştur ${ }^{[4]}$.

C1 pozitif sonuçlardan kaynaklandığı bildirilmesine rağmen bu hastaların takibi ve düșük pozitif test sonuçlarının bir doğrulama testi ile ayrıca değerlendirilmesi önerilmektedir ${ }^{[17]}$. ELISA testlerindeki yalanc1 pozitiflik problemi özellikle $\mathrm{HCV}$ seroprevalansının düșük olduğu bölgelerde (< \%3) daha sık görülmektedir ${ }^{[16,17]}$. ELISA testlerinde "düșük-yanlıs" pozitif test sonucu ile ilișkili olabilen durumlar arasında süpresyona bağlı azalmıs immün yanıt, yașlı hastalarda görülebilen düșük titreli test pozitifliği, iyileșmiș $\mathrm{HCV}$ infeksiyonlarında yıllar içerisinde antikor düzeylerinde azalma göruilmesi gibi durumlar yer alır ${ }^{[17]}$. En önemli nedenlerden biri de tekrarlayan düsüuk pozitiflik durumları ile de ilișkili olabilen biyolojik yanlış pozitiflik olasılığıdır. Biyolojik yanlıș pozitifliğin en sık karșılașılan nedenleri diğer viral infeksiyonlara (sitomegalovirüs, Epstein-Barr virüs, HIV, hepatit A virüsü ve hepatit $B$ virüsü) bağlı çapraz reaktivite, sistemik lupus eritematozus hastaları, romatoid faktör pozitifliği olan hastalar ve yakın zamanda yapılan așı uygulamalarıdır (influenza așısı gibi) [17]. Geçirilmiș ve iyileșmiş HCV infeksiyonunu, HCV antikoru için biyolojik yanlıș pozitiflikten (özgün olmayan antikor-antijen etkileșimlerine bağli) ayırt etmek için, farklı bir $\mathrm{HCV}$ antikor testinin (RIBA, LIA veya farklı bir ticari ELISA testi) yapılması da düșünülebilir ${ }^{[8]}$. Geçmiște RIBA veya LIA gibi özgülliuğui daha yüksek testler doğrulama aracı olarak kullanılmıștır ${ }^{[17]}$. Bununla birlikte, pozitif anti-HCV ELISA ve negatif veya belirsiz immünblot test sonucu bulunan kan bağısçılarının \%20'sinde HCV-RNA saptanabildiği bildirilmektedir $^{[7]}$. Ülkemizde gecmiș yıllarda șüpheli örneklerin doğrulama amaçlı olarak Halk Sağlığı Referans Laboratuvarlarına gönderilmesi seklinde uygulamalar olmus ise de RIBA testi günümüz laboratuvar pratiğinde doğrulama testi olarak kullanılmamaktadır ${ }^{[16]}$. Günümüzde süpheli pozitif serolojik test sonuçlarının doğrulanmasında serolojik yöntemlere göre daha duyarlı yöntemler olan ve pencere dönemindeki infekte kișilerde ve immünsüpresif bireylerde daha doğru değerlendirmeler yapılmasına imkan veren HCV-RNA testlerinin kullanımı her geçen gün yaygınlașmaktadır. Yapılan çalıșmalarda düsüuk pozitif anti-HCV varlığı saptanan örneklerde genel olarak HCV-RNA saptanamazken, bazı calıșmalarda düșük oranlarda HCV-RNA pozitifliği bildirilmiștir. Moleküler testlerin maliyet etkinliği dikkate alınarak, hastanın kliniği, süupheli maruziyet öyküsü ve biyokimyasal test sonuçları birlikte değerlendirildikten sonra antikor pozitifliğinin doğrulanmasında moleküler testlerin kullanılmasının uygun olacağı belirtilmektedir ${ }^{[17]}$. Bağıșıklığı baskılanmıș kișiler ve hemodiyaliz hastaları için ise anti-HCV sonucuna bakılmaksızın HCV-RNA testinin yapılması düșünülmelidir ${ }^{[8]}$. Gereksiz endișelere neden olabilmesi nedeniyle anti-HCV sonuçlarının yüksek pozitif, düșük pozitif ve negatif olarak bildirilmesi de önerilmektedir ${ }^{[17]}$. Tedavi kararlarının yönlendirilmesine yardım etmek için tedaviye bașlamadan önce 


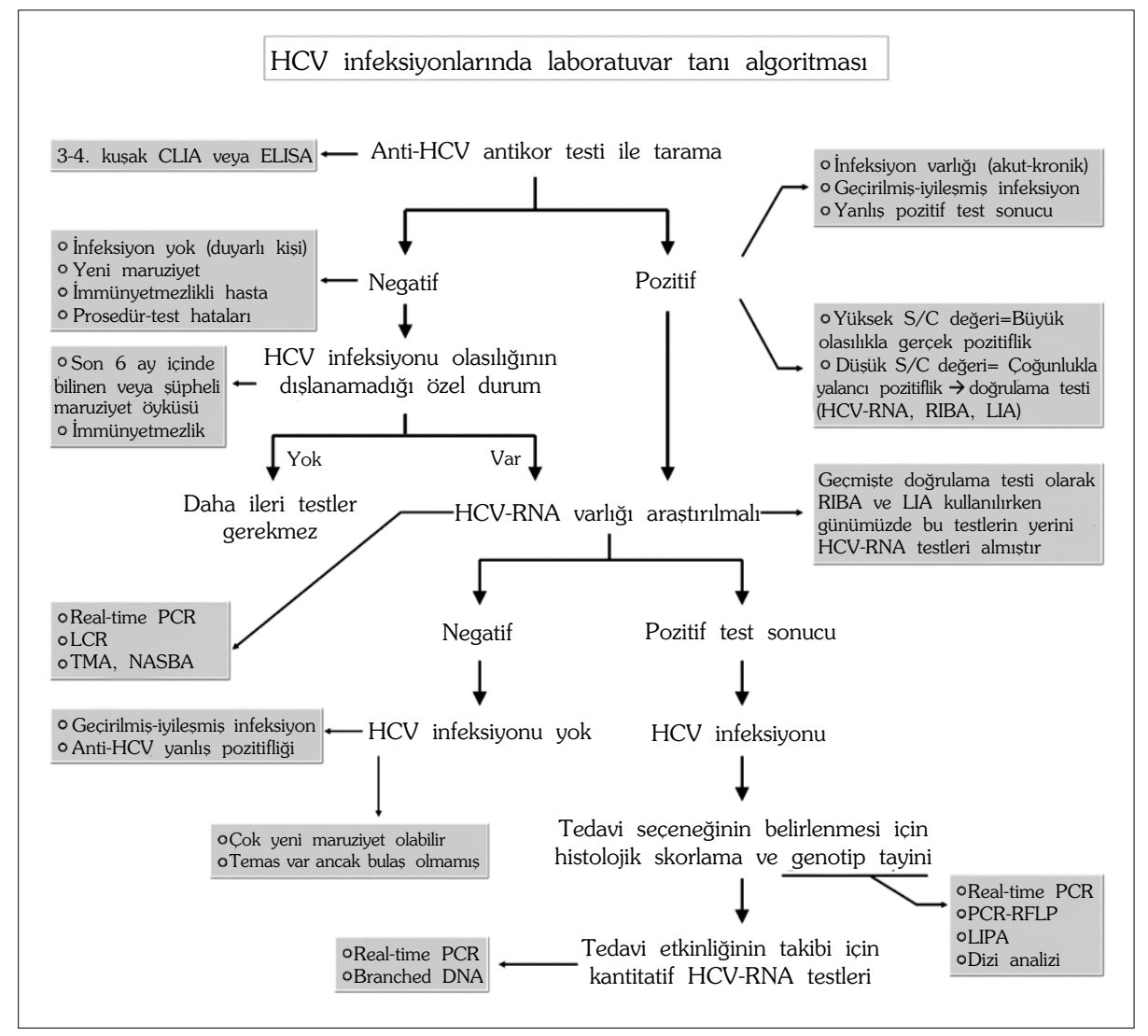

Şekil 2. HCV infeksiyonlarında tanı algoritması ve test sonuçlarının gösterdiği olasıııklar ${ }^{[6-9,17,19,53]}$. Kısıtlı imkanlara sahip bölgeler için HCV antikorlarındaki reaktivite sonrası HCV antijenemi (kor) testi önerilse de bu yaklaşım ülkemizde rutin pratikte uygulanmamaktadır ${ }^{[8,19]}$.

kantitatif HCV-RNA testleri ile bazal viral yükün belirlenmesi ve $\mathrm{HCV}$ genotip tayininin yapilması da günümüzde rutin tanının bir parçası haline gelmiștir. Ayrıca, tedavinin aciliyetini belirlemek için karaciğer biyopsisi veya invaziv olmayan bir test ile karaciğer fibrozis derecesinin değerlendirilmesi de gerekebilir ${ }^{[6]}$. Klinik laboratuvarlar kalite kontrol uygulamaları kapsamında laboratuvar imkanlarına göre HCV tanı algoritmalarını olușturmalı ve düzenli olarak güncellemelidir (Șekil 2).

Sonuc olarak, mikrobiyolojik testler HCV infeksiyonlarının tanısı, tedavi planlaması ve takibinde kritik önem kazanmıs ve bu önemi her geçen gün artmaktadır. Yeni gelistirilen antiviraller ve tedavi protokollerinin genotip-subtip düzeyindeki etkinlikleri, epidemiyolojik calıșmalar, akut infeksiyonlar ve süpheli maruziyetlerde erken tanı, tedavi planlaması, tedavi etkinliğinin izlenmesi ve prognoz öngörüsü mikrobiyolojik tanının önemli katkıları olarak sıralanabilir. Düșük veya yanlıs pozitif serolojik test sonuçlarının neden olduğu endișelerin ve ek maliyetlerin asgari düzeylere cekilmesi ve infekte olguların erken tespiti için güncel verilere göre hazırlanan tanı algoritmalarının izlenmesi yararlı olacaktır.

\section{ÇIKAR ÇATIŞMASI}

Yazarlar bu makale ile ilgili herhangi bir çkar çatıșması bildirmemișlerdir.

\section{KAYNAKLAR}

1. Scheel TK, Rice CM. Understanding the hepatitis C virus life cycle paves the way for highly effective therapies. Nat Med 2013;19(7):837-49.

2. International Committee on Taxonomy of Viruses, Washington, DC. Virus Taxonomy: 2018b, July 2018. Available at: https://talk.ictvonline.org/taxonomy/ [Accessed July 26, 2019].

3. Messina JP, Humphreys I, Flaxman A, Brown A, Cooke CS, Pybus OG, et al. Global distribution and prevalence of hepatitis C virus genotypes. Hepatology 2015;61(1):77-87. 
4. Şanlıdağ T, Akçalı S, Ecemiș $T$, Süer K, Erbay Dündar P, Arıkan $A$ ve ark. Hepatit $C$ virus (HCV) enfeksiyonunun tanısında anti-HCV düzeyi (S/Co) ile HCV-RNA arasındaki korelasyonun araştırılması. Mikrobiyol Bul 2016;50(3):508-10.

5. Tozun N, Ozdoğan O, Cakaloğlu Y, Idilman R, Karasu Z, Akarca $U$, et al. Seroprevalence of hepatitis $B$ and $C$ virus infections and risk factors in Turkey: a fieldwork TURHEP study. Clin Microbiol Infect 2015;21(11):1020-6.

6. Wilkins T, Akhtar M, Gititu E, Jalluri C, Ramirez J. Diagnosis and management of hepatitis C. Am Fam Physician 2015;91(12):835-42

7. Huber MK, Sarrazin U, Zeuzem S. Hepatitis $C$ virus (chapter 10). In: Rübsamen-Waigmann H, Deres K, Hewlett $G$, Welker $R$ (eds). Viral Infections and Treatment. New York: Marcel Dekker Inc, 2003:295-367.

8. Cloherty G, Talal A, Coller K, Steinhart C, Hackett J Jr, Dawson $G$, et al. Role of serologic and molecular diagnostic assays in identification and management of hepatitis $C$ virus infection. J Clin Microbiol 2016;54(2):265-73.

9. Ghany MG, Liang TJ. Natural history of chronic hepatitis C. In: Miyamura T, Lemon SM, Walker CM, Wakita T (eds). Hepatitis C Virus II: Infection and Disease. Springer Japan, 2016:3-56.

10. Westbrook RH, Dusheiko G. Natural history of hepatitis C. I Hepatol 2014;61(1 Suppl):S58-68.

11. Gupta E, Bajpai M, Choudhary A. Hepatitis C virus: screening, diagnosis, and interpretation of laboratory assays. Asian J Transfus Sci 2014;8(1):19-25.

12. Ahmed Z, Ahmed U, Walayat S, Ren J, Martin DK, Moole $H$, et al. Liver function tests in identifying patients with liver disease. Clin Exp Gastroenterol 2018;11:301-7.

13. Zhang W, Wang L, Wang L, Li G, Huang A, Yin P, et al. Liver stiffness measurement, better than APRI, fibroindex, Fib-4, and NBI gastroscopy, predicts portal hypertension in patients with cirrhosis. Cell Biochem Biophys 2015;71(2):865-73.

14. Lanford RE, Walker CM, Lemon SM. The chimpanzee model of viral hepatitis: advances in understanding the immune response and treatment of viral Hhepatitis. ILAR J 2017;58(2):172-89.

15. Coppola N, Pisapia R, Tonziello G, Masiello A, Martini S, Pisaturo $M$, et al. Improvement in the aetiological diagnosis of acute hepatitis C: a diagnostic protocol based on the anti-HCV-IgM titre and IgG avidity index. I Clin Virol 2009;46(3):222-9.

16. Tanrıcı Baştuğ A, Bodur H. Akut hepatit C tanı ve tedavisi: literatüre bakış. Viral Hepatit Dergisi 2007;12(2):62-7.

17. Uzun B, Er H, Güngör S, Şener AG, Kaya S. Düşük titrede anti-HCV pozitifliği bulunan hastalarda rekombinant immunoblot (RIBA) ve HCV-RNA test sonuçlarının değerlendirilmesi. J Clin Exp Invest 2014;5(4):553-6.

18. Coşkun Ö, Savaş̧̧ı Ü. Hepatit C virüs enfeksiyonunun patogenezi ve doğal seyri. TAF Prev Med Bull 2012;11(4):489-98.

19. Kumar A, Rajput MK, Paliwal D, Yadav A, Chhabra R, Singh S. Genotyping \& diagnostic methods for hepatitis $C$ virus: a need of low-resource countries. Indian I Med Res 2018;147(5):445-55.
20. Yenicesu i, Ertuğrul Örüç N. Mikrobiyolojik testler. Yenicesu i, Ertuğrul Örüç N (editörler). Ulusal Kan ve Kan Bileşenleri Hazırlama, Kullanım ve Kalite Güvencesi Rehberi. Ankara: Sağlık Bakanlığı Yayınları (Numara: 1016), 2016:154-98.

21. Colquillo Aysallanque B, Sanchez Montano R, Terceros Almanza $P$. New strategies in the diagnosis and treatment of hepatitis C. Evaluation of RT-PCR and EIA laboratory techniques. Biofarbo 2009;17(2):15-22.

22. Tillmann HL, McHutchison JG. Hepatitis C (chapter 31). In: Boyer TD, Manns MP, Sanyal AJ, Zakim D (eds). Zakim and Boyer's Hepatology: A Textbook of Liver Disease. Philadelphia: Elsevier Sounders, 2012:564-98.

23. Delage G. Clinician's guide to diagnostic tests for hepatitis C virus infections. Can J Infect Dis 1993;4(3):170-1.

24. Taliani G, Badolato MC, Lecce R, De Bac C, De Marzio E, Balsano $C$, et al. Recombinant immunoblot assay for hepatitis $C$ virus antibody in chronic hepatitis. Arch Virol Suppl 1992;4:232-3.

25. Donyavi T, Bokharaei-Salim F, Khanaliha K, Sheikh M, Bastani MN, Moradi N, et al. High prevalence of occult hepatitis $C$ virus infection in injection drug users with HIV infection. Arch Virol 2019;164(10):2493-504.

26. Zayed RA, Rushdy E, Saleh DA. Detection of HCV RNA in the peripheral blood mononuclear cells of serum HCV RNA-negative Egyptian patients under interferon treatment. Am J Med Sci 2010; 40(6):435-8.

27. Maasoumy $B$, Vermehren J. Diagnostics in hepatitis C: the end of response-guided therapy? J Hepatol 2016;65(1 Suppl):S67-S81.

28. Germer JJ, Heimgartner PJ, IIstrup DM, Harmsen WS, Jenkins GD, Patel R. Comparative evaluation of the Versant HCV RNA 3.0, Quantiplex HCV RNA 2.0, And Cobas Amplicor HCV Monitor version 2.0 Assays for quantification of hepatitis $C$ virus RNA in serum. I Clin Microbiol 2002;40(2):495-500.

29. Bartenschlager $R$, Baumert TF, Bukh J, Houghton M, Lemon $S M$, Lindenbach $B D$, et al. Critical challenges and emerging opportunities in hepatitis $C$ virus research in an era of potent antiviral therapy: considerations for scientists and funding agencies. Virus Res 2018;248:53-62.

30. Cuypers L, Thijssen M, Shakibzadeh A, Sabahi F, Ravanshad $M$, Pourkarim MR. Next-generation sequencing for the clinical management of hepatitis C virus infections: does one test fits all purposes? Crit Rev Clin Lab Sci 2019;56(6):420-34.

31. Cebeci I, Tanoglu A, Şahiner F, Özel M, Öncü K, Yazgan Yve ark. Kronik hepatit C hastalarında antiviral tedaviye yanıtta etkili olabilecek parametrelerin değerlendirilmesi. Gülhane Tip Derg 2015;57:373-7.

32. Ergünay $K$, Abacıoğlu $H$. Hepatit $C$ virusunun genomik varyasyonları ve kliniğe etkileri. Mikrobiyol Bul 2015;49(4):625-35.

33. Kabakçı Alagöz G, Karataylı SC, Karataylı E, Celik E, Keskin $O$, Dinç $B$, et al. Hepatitis $C$ virus genotype distribution in Turkey remains unchanged after a decade: performance of phylogenetic analysis of the NSSB,E1, and $5^{\prime} U T R$ regions in genotyping efficiency. Turk J Gastroenterol 2014;25(4):405-10. 
34. Quer I, Gregori I, Rodriguez-Frias F, Buti M, Madejon $A$, Perez-del-Pulgar $S$, et al. High-resolution hepatitis $C$ virus subtyping using NS5B deep sequencing and phylogeny, an alternative to current methods. I Clin Microbiol 2015;53(1):219-26.

35. Cuypers $L$, Thijssen $M$, Shakibzadeh A, Sabahi F, Ravanshad $M$, Pourkarim MR. Next-generation sequencing for the clinical management of hepatitis $C$ virus infections: does one test fits all purposes? Crit Rev Clin Lab Sci 2019;56(6):420 34.

36. Chen Z, Weck KE. Hepatitis C virus genotyping: interrogation of the $5^{\prime}$ untranslated region cannot accurately distinguish genotypes $1 a$ and $1 b$. I Clin Microbiol 2002;40(9):3127-34.

37. Yang $R$, Cong $X, D u S$, Fei R, Rao H, Wei L. Performance comparison of the versant HCV genotype 2.0 assay (LiPA) and the abbott realtime HCV genotype II assay for detecting hepatitis $C$ virus genotype 6. J Clin Microbiol 2014;52(10):3685-92.

38. Liu CH, Liang CC, Liu Cl, Lin CL, Su TH, Yang HC, et al. Comparison of abbott real-time HCV genotype II with versant line probe assay 2.0 for hepatitis $C$ virus genotyping. J Clin Microbiol 2015;53(5):1754-7.

39. Fernandez-Caso B, Fernandez-Caballero JA, Chueca N, Rojo $E$, de Salazar A, Garcia Buey L, et al. Infection with multiple hepatitis $C$ virus genotypes detected using commercial tests should be confirmed using next generation sequencing. $\mathrm{SC}$ Rep 2019;9(1):9264.

40. Olmstead AD, Montoya V, Chui CK, Dong W, Joy JB, Tai V, et al. A systematic, deep sequencing-based methodology for identification of mixed-genotype hepatitis $C$ virus infections. Infect Genet Evol 2019;69:76-84.

41. Kulah C, Altindis M, Akyar I, Gokahmetoglu S, Sayiner A, Kaleli I, et al. The prevalence of mixed genotype infections in Turkish patients with hepatitis C: a multicentered assessment. Clin Lab 2019;65(4).

42. Hayashi K, Tachi K, Shimizu Y, Nagano K, Ishizu Y, Kuzuya $T$, et al. The prevalence of mixed hepatitis $C$ virus genotype infection and its effect on the response to direct-acting antivirals therapy. Intervirology 2019;62(1):23-9.

43. McNaughton AL, Sreenu VB, Wilkie G, Gunson R, Templeton $K$, Leitch ECM. Prevalence of mixed genotype hepatitis $C$ virus infections in the UK as determined by genotype-specific PCR and deep sequencing. I Viral Hepat 2018;25(5):52434.
44. Lin S, Arcangel P, Medina-Selby A, Coit D, Ng P, Nguyen S, et al. Design of novel conformational and genotype-specific antigens for improving sensitivity of immunoassays for hepatitis C virus-specific antibodies. I Clin Microbiol 2005;43(8):3917-24.

45. van Doorn LJ, Kleter B, Pike I, Quint W. Analysis of hepatitis $C$ virus isolates by serotyping and genotyping. I Clin Microbiol 1996;34(7):1784-7.

46. Pawlotsky JM, Negro F, Aghemo A, Berenguer $M$, Dalgard $O$, Dusheiko G, et al. (European Association for the Study of the Liver). EASL recommendations on treatment of hepatitis C 2018. J Hepatol 2018;69(2):461-511.

47. Fourati S, Pawlotsky JM. Virologic tools for HCV drug resistance testing. Viruses 2015;7(12):6346-59.

48. Dirani G, Paesini E, Mascetra E, Farabegoli P, Dalmo B, Bartolini $B$, et al. A novel next generation sequencing assay as an alternative to currently available methods for hepatitis $C$ virus genotyping. I Virol Methods 2018;251:88-91.

49. Gao F, Talbot EA, Loring CH, Power JJ, Dionne-Odom J, Alroy-Preis $S$, et al. Performance of the OraQuick HCV rapid antibody test for screening exposed patients in a hepatitis $C$ outbreak investigation. J Clin Microbiol 2014;52(7):2650-2.

50. Khuroo MS, Khuroo NS, Khuroo MS. Diagnostic accuracy of point-of-care tests for hepatitis $C$ virus infection: a systematic review and meta-analysis. PLOS One 2015;10(3):e0121450.

51. Kıratı K, Gül HC, Artuk C, Kozan S, Öztuna A, Tunca Y ve ark. Kronik hepatit $C$ enfeksiyonu olan hastalarda paraoksonaz-1 gen polimorfizmi ile tedaviye yanıt arasındaki ilişkinin Aaraştırılması. Mikrobiyol Bul 2014;48(4):596-605.

52. Lange CM, Zeuzem S. IL28B single nucleotide polymorphisms in the treatment of hepatitis C. J Hepatol 2011;55(3):692-701.

53. Centers for Disease Control and Prevention, USA. Available at: https://www.cdc.gov/hepatitis/resources/professionals/ training/serology/training.htm [Accessed July 25, 2019].

\section{Yazıșma Adresi/Address for Correspondence}

Doc. Dr. Fatih SAHINER

Sağlık Bilimleri Üniversitesi Gülhane Tıp Fakültesi, Tibbi Mikrobiyoloji Anabilim Dalı,

Ankara-Türkiye

E-posta: fsvirol@gmail.com 